\title{
Farklı Kuşaklardaki Hemşirelerin İş Doyumunun Belirlenmesi
}

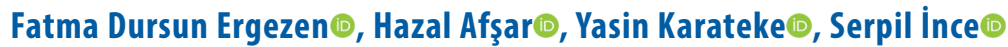

Akdeniz Üniversitesi, Hemşirelik, Antalya, Türkiye

Fatma Dursun Ergezen, Arş. Gör. Hazal Afşar, Hemşire Yasin Karateke, Hemşire Serpil İnce, Dr. Öğr. Üyesi

Illetişim:

Arş. Gör. Fatma Dursun Ergezen Akdeniz Üniversitesi, Hemşirelik, Antalya, Türkiye

Tel: +902422492999

E-Posta: fatmadursn@gmail.com

Gönderilme Tarihi : 20 Şubat 2018

Revizyon Tarihi : 08 Haziran 2018

Kabul Tarihi : 26 Haziran 2018

\section{ÖZET}

Amaç: Bir üniversite hastanesinde çalışan farklı kuşaklardaki hemşirelerin iş doyumunun belirlenmesidir.

Gereç ve Yöntem: Tanımlayıcı tipte olan araştırma bir üniversite hastanesinde çalışan 204 hemşire ile yapılmıştır. Araştırma verileri “Hemşire Tanıtım Formu” ve "Minnesota İ̧̧ Doyum Ölçeği” ile toplanmıştır. Verilerin değerlendirilmesinde, tanımlayıc istatistikler, Kruskal Wallis ve Mann-Whitney U testi kullanılmıştır.

Bulgular: Araştırmaya katılan hemşirelerin \%89,7'si kadın ve \%78,9'u lisans mezunudur. Hemşirelerin \%36,8'i yoğun bakım ünitesinde, $\% 27,9^{\prime}$ u dahili kliniklerde, $\% 24,5^{\prime} \mathrm{i}$ cerrahi kliniklerde, $\% 10,8^{\prime} \mathrm{i}$ polikliniklerde çalışmaktadır. Hemşirelerin \%2,9'u Büyük Bebek Patlaması kuşağında, \%24,5'i X kuşağında, \%72,5'i Y kuşağındadır. Büyük Bebek Patlaması kuşağındaki hemşirelerin iş doyumu puan ortalaması $69,02 \pm 1,32, X$ kuşağındaki hemşirelerin $61 \pm 1,51$, Y kuşağındaki hemşirelerin ise $57,19 \pm 1,08$ olarak bulunmuştur. Hemşirelerin kuşaklar arası iş doyumu puan ortalamaları arasında istatistiksel olarak anlamlı farkııık bulunmuştur $(p<0,05)$. Büyük Bebek Patlamasının genel iş doyumu düzeyinin $\mathrm{X}$ ve $\mathrm{Y}$ kuşağından daha yüksek olduğu belirlenmiştir.

Sonuç: Araştırmada, Büyük Bebek Patlaması Kuşağındaki hemşirelerin iş doyumlarının diğer kuşaklara kıyasla yüksek olduğu belirlenmiştir. Hemşirelerin iş doyumlarını artırmak için uygun müdahalelerin yapılması ve sonuçlarının araştırılması önerilmektedir.

Anahtar sözcükler: Hemşirelik, kuşak, iş doyumu, minnesota iş doyum ölçeği

\section{DETERMINATION OF THE JOB SATISFACTION OF NURSES OF DIFFERENT GENERATIONS}

\section{ABSTRACT}

Objectives: The purpose of this study is to determine the job satisfaction of nurses of different generations who work in a university hospital.

Methods: This descriptive research was performed with the 204 nurses who work in a university hospital. The research data were collected with the "Nurse Identification Form" and "Minnesota Satisfaction Questionnaire". Descriptive statistics, Kruskal Wallis and Mann-Whitney U Test were used for the evaluation of research data.

Results: It has been found that most $89,7 \%$ of the participants were females, $78,9 \%$ had bachelor's degree, $36,8 \%$ work in intensive care unit, $27,9 \%$ work in internal diseases clinic, $24,5 \%$ work in surgery clinic and $10,8 \%$ work in polyclinics. $2.9 \%$ of the nurses are in Baby Boomers, $24.5 \%$ are in Generation X and $72.5 \%$ are in Generation Y. The average score for job satisfaction was found to be $69.02 \pm 1.32$ for Baby Boomers nurses while it was $61 \pm 1.51$ for Generation X nurses and $57.19 \pm 1.08$ for Generation Y nurses. A statistically significant difference was detected between the average scores of nurses for job satisfaction in different generations $(p<0,05)$. Job satisfaction was higher in Baby Boomers compared to those of both $X$ and $Y$ Generation.

Conclusion: As a result of the study, it was found that the job satisfaction of Baby Boomers nurses was higher than the other generations. To increase nurses' job satisfaction, it is recommended to make appropriate interventions and investigate the results.

Keywords: Nursing, generation, job satisfaction, minnesota satisfaction questionnaire 
ş doyumu, çalışanların fiziksel, ruhsal ve sosyal gereksinimlerinin beklentileri doğrultusunda karşılanma düzeyidir. Çalışanların işine ve çalışma ortamına yönelik göstermiş olduğu duygusal bir tepki olarak tanımlanmaktadır (1). Iş doyumu, çalışanların iş ortamında mutlu ve üretken olabilmeleri için önemli bir unsur olarak görülmektedir (2). Özellikle iş doyumu, hastane ortamında hem sağlık çalışanlarının hem de kurumun performansını değerlendirmede önemli bir ölçüt olarak kabul edilmektedir (3). Hasta ile 24 saat etkileşimde olan ve hastanın bakımından birebir sorumlu olan hemşirelerin iş doyumunun belirlenmesi bakımın kalitesini değerlendirmek açısından önemlidir.

Literatürde iş doyumunun hemşirelerin bireysel özelliklerinden ve kurumun yapısından etkilendiği bildirilmektedir $(2,4,5)$. Hemşirelerin iş yükündeki artış, çalışma arkadaşları ile yaşanan problemler, çalışma ortamı ve koşullardan memnun olunmaması iş doyumunu azaltmaktadır (6-13). Buna karşılık hemşirelerin mesleğini sevmesi, mesleğine yönelik olumlu bakış açısına sahip olması, mesleki olarak kendini yeterli hissetmesi ise iş doyumunu artıran faktörler olarak ifade edilmektedir $(7,14,15)$.

Hemşirelerin işlerinden doyum almaması beraberinde farklı sorunları getirmektedir. Hemşirelerin uzun süre doyumsuzluk yaşaması tükenmişliğe neden olmakla birlikte (16), hemşirelerin işten ayrılma niyetlerini de arttırmaktadır (2). Hemşirelerin işten ayrılma niyetlerini artıran nedenlerden dolayı, her hemşirenin iş ile ilgili gereksinimlerinin, beklentilerinin ve değerlerinin anlaşılması zorlaşmaktadır (17). Çalışma yaşamında bulunan her bir kuşağın temel değerleri, iş ve örgüte yönelik tutumları farklılık göstermektedir. Söz konusu farklılıklar da çalışma ortamında önemli çatışma ve zorluklara neden olmaktadır. Kuşakların etkin şekilde yönetilmesi için her kuşağın beklentilerine, isteklerine ve eğilimlerine yönelik uygun stratejilerin tasarlanması gerektiği savunulmaktadır (18).

Türk Dil Kurumu kuşak kavramını; "yaklaşık olarak aynı yıllarda doğmuş, aynı çağın şartlarını, dolayısıyla birbirine benzer sıkıntıları, kaderleri paylaşmış, benzer ödevlerle yükümlü olmuş kişilerin topluluğu" olarak tanımlamıştır (19). Kuşak kavramı doğum yılı ya da önemli bir olayla birlikte ortaya çıkmaktadır. Literatürde incelendiğinde; hemşirelikte 4 kuşak olduğundan bahsedilmektedir: Veferans 1945 ve öncesi, Büyük Bebek Patlaması 1946-1964 yılları, X kuşağı 1965-1979, Y kuşağı ise 1980 ve sonrasıdır (2022). Kuşakların çeşitli politik, tarihi ve sosyal olaylardan etkilenmeleri tutum ve davranışlarda farklılıklara neden olmaktadır (23). Literatürde hemşirelerin yer aldığı kuşağa göre iş doyumlarının ve işten ayrılma niyetlerinin farklılaştığı belirtilmektedir (23-25).
Hemşirelerin iş doyumunu etkileyen bireysel ve kurumsal faktörleri araştıran çok sayıda araştırmaya rastlanmıştır $(2,6,8,10,11,16)$. Hemşirelerin yaşının iş doyumunda etkili olduğu araştırmalarda belirtilirken, kuşaklar arasındaki farklılığa dikkat çeken araştırma sayısı kısıtı bulunmuştur (2325). Kuşak özelliklerinin bilinmesi hemşirelerin iş doyumunu artırmak ve işten ayrılma niyetini azaltmak için uygun stratejilerin planlanabilmesi açısından önemlidir. Üstelik bu stratejilerin her kuşağın beklentilerine, isteklerine ve eğilimlerine yönelik planlanabilmesi için iş doyumuna yönelik değerlendirmelerin belirli aralıklarla düzenli olarak yapılması gerekmektedir. Bu bağlamda bu araştırma, bir üniversite hastanesinde çalışan farklı kuşaktaki hemşirelerin iş doyumunun belirlenmesi amacıyla yapılmıştır.

\section{Gereç ve yöntem}

\section{Araştırma amacı ve türü}

Araştırma bir üniversite hastanesinde çalışan farklı kuşaktaki hemşirelerin iş doyumunu belirlemek amacıyla tanımlayıcı olarak yapılmıştır.

\section{Araştırmanın örneklemi}

Araştırmanın evrenini Akdeniz Bölgesinde bir üniversite hastanesinde çalışan 722 hemşire oluşturmaktadır. Araştırmanın örneklem büyüklüğü evreni bilinen örneklem formülüne $\left[n=\left(N . t^{2} p . q\right) /\left(d^{2}\right.\right.$. (N-1)+ $\left.\left.t^{2} p . q\right)\right]$ göre 251 hemşire olarak hesaplanmıştır. Araştırmaya katılmayı kabul eden 204 hemşire araştırmanın örneklemini oluşturmuştur.

\section{Verilerin toplanması}

Araştırma verileri Ocak-Mart 2017 tarihlerinde "Hemşire Tanıtım Formu" ve "Minnesota İş Doyum Ölçeği" ile toplanmıştır. Veri toplama sürecinde hemşirelere araştırmanın amacı açıklanmış ve onamları alınmıştır. Araştırmaya katılmayı kabul eden hemşireler tarafından "Hemşire Tanıtım Formu" ve "Minnesota İş Doyum Ölçeği" doldurulmuştur.

\section{Veri toplama araçları}

Hemşire Tanıtım Formu: Araştırma verileri araştırmacı/araştırmacılar tarafından geliştirilen hemşirelerin doğum yılı, cinsiyeti, eğitim durumu, klinikteki, kurumdaki ve meslekteki çalışma süresi, kadro durumu, birimden, kurumdan ve meslekten ayrılma niyetlerini içeren sekiz sorudan oluşmaktadır.

Minnesota Iş Doyum Ölçeği: Ölçek, Weiss ve arkadaşları (26) tarafından iş doyumunu ölçmek amacıyla geliştirilmiş ve Türkçe geçerlilik ve güvenilirliği Baycan (27) tarafından yapılmıştır. Minnesota İş Doyum Ölçeği 1-5 arasında puanlanan beşli likert tipi bir ölçektir. Ölçek, hiç memnun değilim (1 puan), memnun değilim (2 puan), kararsızım (3 puan), memnunum (4 puan), çok memnunum (5 puan) olarak değerlendirilmektedir. Ölçekte ters soru bulunmamaktadır. Minnesota İş Doyum Ölçeği içsel, dışsal ve genel doyum düzeyini belirleyici özelliklere sahip 20 maddeden 
oluşmaktadır. İçsel doyum, 1, 2, 3, 4, 7, 8, 9, 10, 11, 15, 16 maddelerini kapsamaktadır. Dışsal doyum 5, 6, 12, 13, 14, $17,18,19$ maddelerinden oluşmaktadır. Genel doyum ise ölçeğin tüm maddelerini kapsamaktadır. İçsel, dışsal ve genel doyum puanları, her bir faktörü oluşturan maddelerin puanları toplamının madde sayısına bölünmesi ile elde edilmektedir. Ölçeğin nötr doyum puanı 3'tür. Ölçekten alınan puan 3'ten küçük ise iş doyumu düşük, 3'ten büyük ise iş doyumu yüksek olarak değerlendirilmektedir (27).

\section{Verilerin değerlendirilmesi}

Araştırma verilerinin analizi SPSS (Statistical Package for Social Sciences) 23.0 istatistik paket programı ile yapılmıştır. Verilerin değerlendirilmesinde tanımlayıc istatistikler (yüzde, ortalama, standart sapma), ölçek puan ortalamaIarının karşılaştırmalarında Mann Whitney $U$ ve Kruskal Wallis testleri kullanılmıştır.

\section{Araştırmanın sınırlılıkları}

Veri toplama aşamasında araştırmanın yapıldığı yerde aynı dönemde birden fazla araştırmanın yürütülmesi ve bu nedenle hemşirelerin isteksiz olması ulaşılan örneklem sayısını sınırlamıştır. Ayrıca Büyük Bebek Patlaması kuşağındaki hemşirelerin araştırmaya katılmak istememesi ve erkek hemşire sayısının az olması araştırmanın bir diğer sınırlılığı olarak söylenebilir. Araştırmadan elde edilen bulgular doğrultusunda yapılan değerlendirmeler, araştırmanın örneklemi ile sınırlıdır.

\section{Araştırmanın etik yönü}

Araştırmanın yapılabilmesi için Akdeniz Üniversitesi Klinik Araştırmalar Etik Kurulundan onay alınmıştır (Etik Kurul Tarihi:06/12/2016, Karar Numarası:70904504/552). Araştırmaya başlamadan önce araştırmanın yapıldığı kurumdan izin alınmıştır.

\section{Bulgular}

Araştırmaya katılan hemşirelerin \%89,7'si kadın, \%78,9'u li-

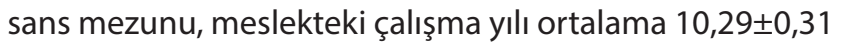
ve birimdeki çalışma yılı 4,12 $\pm 0,56$ 'dır. Hemşirelerin $\% 36,8^{\prime}$ i yoğun bakım ünitesinde, $\% 27,9$ 'u dahili kliniklerde, $\% 24,5^{\prime} i$ cerrahi kliniğinde ve $\% 10.8$ 'i poliklinikte çalışmaktadır. Hemşirelerin \%66,2'si kadrolu hemşire olarak görev yapmaktadır (Tablo 1).

Tablo 1. Hemşirelerin demografik özelliklerine göre iş doyumu puan ortalamalarının dağılımı $(n=204)$

\begin{tabular}{|c|c|c|c|c|c|}
\hline Özellikler & $n$ & $\%$ & İçsel Doyum Puanı & Dışsal Doyum Puanı & Genel Doyum Puanı \\
\hline \multicolumn{6}{|l|}{ Cinsiyet } \\
\hline Erkek & 21 & 10,3 & $36,12 \pm 7,98$ & $18,24 \pm 5,78$ & $56,95 \pm 1,33$ \\
\hline Kadın & 183 & 89,7 & $36,30 \pm 7,79$ & $19,99 \pm 4,68$ & $58,64 \pm 1,21$ \\
\hline \multirow[t]{2}{*}{ İstatistiksel Anlamlılık } & & & $Z=-0,306$ & $Z=-1,152$ & $Z=-0,383$ \\
\hline & & & $p=0,759$ & $p=0,249$ & $p=0,702$ \\
\hline \multicolumn{6}{|l|}{ Çalışılan Klinik } \\
\hline Yoğun Bakım Ünitesi & 75 & 36,8 & $34,36 \pm 9,00$ & $18,76 \pm 5,48$ & $55,26 \pm 1,41$ \\
\hline Dahili Birimler & 57 & 27,9 & $37,08 \pm 5,49$ & $20,33 \pm 3,60$ & $60,03 \pm 8,70$ \\
\hline Cerrahi Birimler & 50 & 24,5 & $35,95 \pm 6,87$ & $20,02 \pm 4,39$ & $58,30 \pm 1,06$ \\
\hline Poliklinik & 22 & 10,8 & $41,54 \pm 7,74$ & $21,57 \pm 5,56$ & $65,73 \pm 1,38$ \\
\hline \multirow[t]{2}{*}{ İstatistiksel Anlamlılık } & & & $x^{2}=2,190$ & $x^{2}=2,715$ & $x^{2}=3,716$ \\
\hline & & & $p=0,335$ & $p=0,257$ & $p=0,156$ \\
\hline \multicolumn{6}{|l|}{ Kadro Durumu } \\
\hline Kadrolu & 135 & 66,2 & $36,70 \pm 7,82$ & $19,28 \pm 4,76$ & $58,21 \pm 1,24$ \\
\hline Sözleşmeli & 42 & 20,6 & $35,22 \pm 7,31$ & $20,34 \pm 4,91$ & $58,22 \pm 1,19$ \\
\hline Diğer & 27 & 13,2 & $35,87 \pm 8,44$ & $21,62 \pm 4,63$ & $60,17 \pm 1,24$ \\
\hline \multirow[t]{2}{*}{ İstatistiksel Anlamlılık } & & & $x^{2}=1,491$ & $x^{2}=5,866$ & $x^{2}=0,682$ \\
\hline & & & $p=0,475$ & $p=0,053^{*}$ & $p=0,711$ \\
\hline \multicolumn{6}{|l|}{ Eğitim Durumu } \\
\hline Lise & 23 & 11,3 & $37,41 \pm 7,86$ & $21,70 \pm 4,97$ & $61,47 \pm 1,21$ \\
\hline Lisans & 161 & 78,9 & $36,09 \pm 7,86$ & $19,71 \pm 4,70$ & $58,22 \pm 1,23$ \\
\hline Lisansüstü & 20 & 9,8 & $36,59 \pm 7,40$ & $18,49 \pm 5,23$ & $57,02 \pm 1,23$ \\
\hline \multirow[t]{2}{*}{ İstatistiksel Anlamlılık } & & & $x^{2}=0,510$ & $x^{2}=2,413$ & $x^{2}=0,972$ \\
\hline & & & $p=0,475$ & $p=0,120$ & $p=0,324$ \\
\hline \multicolumn{6}{|l|}{ Meslekteki Calısma Yılı } \\
\hline $0-5$ & 76 & 37,3 & $35,75 \pm 7,16$ & $19,84 \pm 4,56$ & $58,02 \pm 1,11$ \\
\hline $6-10$ & 47 & 23 & $34,91 \pm 7,20$ & $19,40 \pm 4,20$ & $56,76 \pm 1,09$ \\
\hline 11 ve üzeri & 81 & 39,7 & $37,58 \pm 8,54$ & $20,02 \pm 5,39$ & $59,88 \pm 1,39$ \\
\hline \multirow[t]{2}{*}{ İstatistiksel Anlamlılık } & & & $x^{2}=4,063$ & $x^{2}=0,789$ & $x^{2}=2,459$ \\
\hline & & & $p=0,131$ & $p=0,674$ & $p=0,324$ \\
\hline \multicolumn{6}{|l|}{ Birimdeki Çalışma Yılı } \\
\hline $0-5$ & 160 & 78,4 & $36,55 \pm 7,51$ & $20,10 \pm 4,72$ & $59,12 \pm 1,17$ \\
\hline $6-10$ & 28 & 13,7 & $35,87 \pm 6,52$ & $19,08 \pm 3,71$ & $56,96 \pm 9,49$ \\
\hline 11 ve üzeri & 16 & 7,8 & $34,35 \pm 1,19$ & $18,23 \pm 6,97$ & $54,55 \pm 1,96$ \\
\hline \multirow[t]{2}{*}{ İstatistiksel Anlamlılık } & & & $x^{2}=0,359$ & $x^{2}=2,073$ & $x^{2}=1,564$ \\
\hline & & & $p=0,836$ & $p=0,355$ & $p=0,457$ \\
\hline
\end{tabular}


Hemşirelerin iş doyumu madde puan ortalamaları Grafik 1'de gösterilmiştir. Hemşirelerin "başkaları ile bir şeyler yapabilme olanakları olmasından" yüksek oranda memnun oldukları, "yaptıkları iş karşılığında aldıkları ücretten" düşük oranda memnun oldukları belirlenmiştir (Grafik 1). Hemşirelerin çalıştığı klinik ve eğitim durumuna göre iş doyumu puan ortalamaları arasında istatistiksel olarak anlamlı fark bulunmamıştır ( $p>0,05)$. Yoğun bakım ünitesinde çalışan hemşirelerin iş doyumu puan ortalamasının en düşük, polikliniklerde çalışan hemşirelerin ise en yüksek olduğu belirlenmiştir (Tablo 1).

Kuşaklara göre hemşirelerin iş doyumu puan ortalamaları arasında istatistiksel olarak anlamlı fark bulunmuştur $(p<0,05)$. Büyük Bebek Patlaması kuşağındaki hemşirelerin iş doyumu puan ortalamaları $X$ ve $Y$ kuşağındaki hemşirelere göre yüksek bulunmuştur. İş doyumu puan ortalaması en düşük Y kuşağındaki hemşirelerden elde edilmiştir (Tablo 2).

Büyük Bebek Patlaması kuşağındaki hemşirelerin \%50'si meslekten "asla" ayrılmayacağını, Y kuşağındaki hemşirelerin \%24,3'ü meslekten "her gün" ayrılmak istediklerini belirtmişlerdir. Hemşirelerin kurumdan ayrılma niyetleri incelendiğinde; Büyük Bebek Patlaması kuşağındaki hemşirelerin $\% 33,3^{\prime}$ ü, $X$ kuşağındaki hemşirelerin \%38'i kurumdan asla ayrılmayacaklarını, $Y$ kuşağındaki hemşirelerin \%34,5'i kurumdan bazen (yılda) ayrılma niyetlerinin olduğunu belirtmişlerdir (Tablo 3).

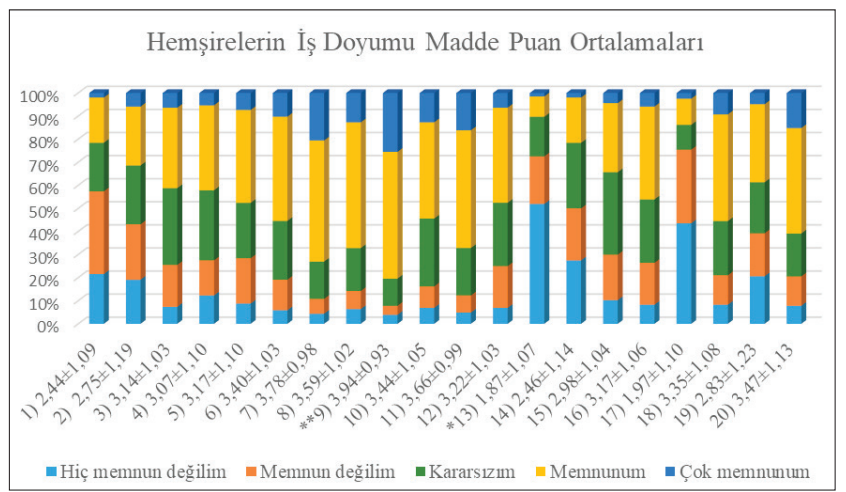

Grafik 1. Hemşirelerin İş Doyumu Madde Puan Ortalamaları

*En düşük madde puan ortalaması, ${ }^{\star \star}$ En yüksek madde puan ortalaması Ölçek Maddeleri: 1) Beni her zaman meşgul etmesinden, 2) Tek başıma çalışamama imkân vermesinden, 3) Ara sıra değişik şeyler yapabilmeme imkân vermesinden, 4) Toplumda saygın bir kişi olma şansını bana vermesinden, 5) Yöneticimin astlarını idare tarzından, 6) Yöneticimin karar vermedeki yeteneğinden, 7) Vicdanıma uygun şeyler yapabilme olanağımın olmasından, 8) Bana sabit bir iş olanağı sağlamasından, 9) Başkaları için bir şeyler yapabilme olanağım olmasından, 10) Kişilere ne yapacaklarını söyleme şansım olmasından, 11) Kendi yeteneklerimle bir şeyler yapabilme şansımın olmasından, 12) İş ile ilgili alınan kararların uygulanmaya konmasından, 13) Yaptığım iş karşıı̆ı̆ında aldığım ücretten, 14) İş de terfi olanağımın olmasından, 15) Kendi kararlarımı uygulama serbestliğini vermesinden, 16) Kendi yeteneklerimi uygulama şansını vermesinden, 17) Çalışma şartlarından, 18) Çalışma arkadaşlarımın birbirleriyle anlaşmalarından, 19) Yaptığım iş karşılığında takdir edilmemden, 20) Yaptığım işten duyduğum başarı hissinden.
Tablo 2. Kuşaklara göre hemşirelerin iş doyumu puan ortalamalarının dağııııı $(n=204)$

\begin{tabular}{lccccc} 
Kuşak & $\boldsymbol{n}$ & $\%$ & $\begin{array}{c}\text { IÇsel } \\
\text { Doyum Puanı }\end{array}$ & $\begin{array}{c}\text { Dışsal } \\
\text { Doyum Puanı }\end{array}$ & $\begin{array}{c}\text { Genel } \\
\text { Doyum Puanı }\end{array}$ \\
\hline $\begin{array}{l}\text { Büyük Bebek } \\
\text { Patlaması }\end{array}$ & 6 & 2,9 & $43,48 \pm 7,66$ & $23,47 \pm 6,01$ & $69,02 \pm 1,32$ \\
X & 50 & 24,5 & $37,96 \pm 9,38$ & $20,60 \pm 5,49$ & $61 \pm 1,51$ \\
Y & 148 & 72,5 & $35,43 \pm 6,97$ & $19,40 \pm 4,46$ & $57,19 \pm 1,08$ \\
İstatistiksel & & & $X^{2}=9,107$ & $X^{2}=5,510$ & $X^{2}=8,571$ \\
Anlamlılık & & $\mathbf{p}=\mathbf{0 , 0 1 1 ^ { * }}$ & $\mathbf{p}=0,064$ & $\mathbf{p}=\mathbf{0 , 0 1 4 ^ { * }}$ \\
\hline${ }^{*} \mathrm{p}<0,05$ & & & &
\end{tabular}

Tablo 3. Kuşaklara göre hemşirelerin meslekten/kurumdan/birimden ayrıma niyetlerinin dağılımı $(\mathrm{n}=204)$

\begin{tabular}{|c|c|c|c|c|}
\hline Özellikler & $\begin{array}{c}\text { Büyük Bebek } \\
\text { Patlaması Kuşağı (\%) }\end{array}$ & $\underset{\text { Kuşağı (\%) }}{X}$ & $\begin{array}{c}Y \\
\text { Kuşağı (\%) }\end{array}$ & $\begin{array}{c}\text { Toplam } \\
\text { (\%) }\end{array}$ \\
\hline \multicolumn{5}{|l|}{$\begin{array}{l}\text { Meslekten } \\
\text { Ayrilma Niyeti }\end{array}$} \\
\hline Asla & 50 & 36 & 12,2 & 19,1 \\
\hline Bazen/yılda & 16,6 & 36 & 39,2 & 37,7 \\
\hline Bazen/ayda & 16,7 & 14 & 15,5 & 15,2 \\
\hline Bazen/haftada & 0 & 0 & 8,8 & 6,4 \\
\hline Her gün & 16,7 & 14 & 24,3 & 21,6 \\
\hline \multicolumn{5}{|l|}{$\begin{array}{l}\text { Kurumdan } \\
\text { Ayrılma Niyeti }\end{array}$} \\
\hline Asla & 33,3 & 38 & 12,2 & 19,1 \\
\hline Bazen/ylda & 33,3 & 36 & 34,4 & 34,8 \\
\hline Bazen/ayda & 16,7 & 8 & 16,2 & 14,2 \\
\hline Bazen/haftada & 0 & 4 & 12,2 & 9,8 \\
\hline Her gün & 16,7 & 14 & 25 & 22,1 \\
\hline \multicolumn{5}{|l|}{$\begin{array}{l}\text { Birimden } \\
\text { Ayrilma Niyeti }\end{array}$} \\
\hline Asla & 33,3 & 32 & 15,5 & 20,1 \\
\hline Bazen/yılda & 33,3 & 32 & 35,2 & 34,3 \\
\hline Bazen/ayda & 16,7 & 16 & 19,6 & 18,6 \\
\hline Bazen/haftada & 0 & 8 & 14,2 & 12,3 \\
\hline Her gün & 16,7 & 12 & 15,5 & 14,7 \\
\hline
\end{tabular}

\section{Tartışma}

Araştırma sonucunda hemşirelerin genel iş doyumu puanları kuşaklara göre incelendiğinde; Büyük Bebek Patlaması kuşağındaki hemşirelerin iş doyumu puan ortalamasının yüksek $(69,02 \pm 1,32)$ Y kuşağındaki hemşirelerin düşük $(57,19 \pm 1,08)$ olduğu saptanmıştır. Ülkemizde $(17,28)$, Amerika Birleşik Devletleri'nde (25) ve Kanada'da (23) yapılan araştırma sonuçlarına göre işlerinden en fazla doyum alan hemşirelerin Büyük Bebek Patlaması kuşağında (17), en az doyum alan hemşirelerin Y kuşağında olması araştırma ile benzerlik göstermektedir. 
Literatürde Büyük Bebek Patlaması kuşağı, idealist, eleştirel düşünme yeteneği yüksek, çalışmak için yaşayan işkolikler olarak tanımlanır (20-22). Ayrıca bu kuşak üyelerinin, hemşireliği bir meslek olarak gördüğü ve en büyük iş yükünün kendilerinde olduğunu düşündükleri belirtilmektedir (22). Araştırmalarda Büyük Bebek Patlaması kuşağındaki hemşirelerin daha deneyimli olması ve mesleki yeterliliklerinin fazla olmasının iş doyumu artıran bir durum olduğu bildirilmektedir $(25,29)$. Mesleğe yeni başlayan ve mesleki deneyimi az olan hemşirelerle yapılan araştırmalarda, hemşirelerin klinik ortamda beklentilerinin karşılanamaması nedeniyle tükenmişlik yaşadıkları ve örgütsel bağlılığın zayıf olmasından kaynaklı olarak iş doyumlarının önemli derecede azaldığı belirtilmektedir (30-32). Bu araştırmada Büyük Bebek Patlaması kuşağının diğer kuşaklara kıyasla iş doyumlarının daha yüksek olmasının, bu kuşağın değer yargılarından, mesleğe bakış açısından ve mesleki yeterliliklerinden kaynaklı olabileceği düşünülmektedir.

Araştırmada $Y$ kuşağındaki hemşirelerin meslekten ayrılma niyetinin (\%24,3), Büyük Bebek Patlaması kuşağındaki $(\% 16,7)$ ve $X$ kuşağındaki (\%14) hemşirelerden yüksek olduğu belirlenmiştir. Bezirci (17), Mert Haydari (33) ve Selçuk Çınar (34)'ın araştırma sonuçlarında da Y kuşağındaki hemşirelerin meslekten ayrılma niyetlerinin yüksek olması araştırma sonucuyla benzerlik göstermektedir. Hemşirelerin meslekten ayrılma niyetlerini inceleyen diğer araştırma sonuçlarıyla (\%66) kıyaslandığında, bu araştırmada hemşirelerin meslekten ayrılma niyetinin oldukça düşük olduğu görülmektedir $(4,35)$.

Hemşirelerin meslekten ayrılma kararını, hemşirenin bireysel özellikleri ve kurumsal faktörler etkilemektedir $(2,3,4,5,7,9)$. Çalışma saatleri, nöbetler ve hemşire sayısının yetersizliği nedeniyle hemşirenin iş yükündeki artış, kurumundan ve ücretten memnun olmama gibi kurumsal faktörler meslekten ayrılma eğilimini artırmaktadır $(4,10,11,24,36-38)$. Hemşirenin mesleki bakış açısı, mesleğe bağlıığı, mesleki beklentilerinin karşılanma düzeyi meslekten ayrılmayı etkileyen diğer unsurlar arasındadır $(2,4,5,15,36)$. Ülkemizde hemşirelerin meslekten ayrılma nedenlerini inceleyen bir araştırmada; en önemli ayrılma nedeninin çalışma koşulları olduğu belirlenmiştir. Özellikle çalışma koşullarının ağır olması, çalışma saatleri, stresli ve güvenli olmayan çalışma çevresi önde gelen nedenler olarak belirtilmiştir. Ayrıca bu araştırmada, hemşireler daha iyi çalışma şartları ve olanakları talep ettikleri için meslekten ayrılmayı düşündükleri ifade etmişlerdir (39). Bu araştırmada, hemşirelerin meslekten ayrılma niyetlerinin diğer araştırmalara oranla daha düşük olması bireysel ve kurumsal faktörlerin daha olumlu olduğunu göstermektedir.
Hemşirelerin meslekten ayrılma niyetlerini inceleyen araştırmalarda; ayrılma niyeti ile yaş, kuşak, mesleki ve kurumsal bağlılık arasında ilişkisi olduğu belirlenmiştir (40-43). Simon, Müller ve Hasselhorn (41), Robson ve Robson (42), Nougureas (40) ve Chang, Du ve Huang (43)'ın araştırmalarında hemşirelerin mesleki bağlılığı arttıkça meslekten ayrılma eğiliminin azaldığı bulunmuştur. Ayrıca Nougureas (40) ve Simon, Müller ve Hasselhorn (41)'un araştırmalarında hemşirelerin yaşı arttıkça iş doyumlarının ve mesleki bağlılıklarının arttığı bu duruma paralel olarak meslekten ayrılma eğilimlerinin azaldığı tespit edilmiştir.

Y kuşağı; kariyer odaklı, takım halinde çalışmayı seven, çalışma ortamının eğlenceli ve yenilikçi olmasını isteyen, bu koşullar sağlanamadığında iş değiştirme niyeti yüksek olan bireyler olarak tanımlanır $(22,44)$. Nitekim Radford, Sharlock ve Bradley (45)'un araştırmalarının sonucunda Y kuşağındaki hemşirelerin meslekte kalmasını etkileyen en önemli unsurların; çalışma arkadaşları ile ilişkiler, ücret ve kariyer olanakları olarak belirlenmesi Y Kuşağının özellikleriyle eşleşmektedir. Kuşaklara göre meslekten ayrılma eğilimine dikkat çeken diğer bir araştırmada; kuşaklar arasında fark olmamasına rağmen tüm kuşaklar daha iyi çalışma ortamı ve koşullarına gereksinim duyduklarını bildirmişlerdir (46). İsveç'te hemşirelerin meslekten ayrılmalarını etkileyen faktörlerin incelendiği bir araştırmada; ücretlerden memnun olmama meslekten ayrılma kararını etkileyen en önemli etmenlerden biri olarak bulunmuştur. Diğer etmenler ise mesleki ilerleme olanaklarının olmaması, görevde yükselme endişesi, yeni iş fırsatlarının olma$\mathrm{SI}$, değişim isteği ve beklentilerin yerine gelmemesi olarak belirlenmiştir. Aynı araştırmada bu kararlar 45 yaşından küçük hemşireler için daha önemli görülmüştür (47). Bu araştırmada $Y$ kuşağındaki hemşirelerin meslekten ayrılma niyetinin diğer kuşaklardan daha yüksek olmasında; mesleki bağlıı̆ı̆n, mesleki beklentilerin yerine getirilmemesinin, çalışma koşullarının ve ücretin etkili olduğu söylenebilir. Nitekim araştırma sonucunda da hemşirelerin memnuniyetsizlik yaşadıkları en önemli konuların "ücret" ve "çalışma koşulları" olduğu görülmektedir (Grafik 1).

\section{Sonuç}

Araştırma sonucunda, Büyük Bebek Patlaması kuşağındaki hemşirelerin iş doyumlarının diğer kuşaklara göre yüksek olduğu belirlenmiştir. Hemşirelerin memnuniyetsizlik yaşadıkların en önemli konuların çalışma koşulları ve ücretler olduğu tespit edilmiştir. Bu bağlamda kurumun, ücretler ve çalışma koşulları konusunda iyileştirme yapması; yönetici hemşirelerin kuşakların beklenti ve değer farklılıklarını dikkate alarak çalışma ortamını daha destekleyici hale getirmesi, mesleğe yeni başlayan hemşirelere oryantasyon programı planlaması önerilmektedir. 


\section{Kaynaklar}

1. Duxbury ML, Armstrong GD, Drew DJ, Henly SJ. Head Nurse Leadership Style with Staff Nurse Burnout and Job Satisfaction in Neonatal Intensive Care Units. Nurs Res 1984;33:97-101. [CrossRef]

2. Lu H, Barriball KL, Zhang $X$, While AE. Job Satisfaction Among Hospital Nurses Revisited: A Systematic Review. Int J Nurs Stud 2012;49:1017-38. [CrossRef]

3. Suárez M, Asenjo M, Sánchez M. Job Satisfaction Among Emergency Department Staff. Australasian Emerg Nurs J 2017;20:31-36. [CrossRef]

4. Yıldız N, Kanan N. Yoğun Bakım Ünitelerinde Çalışan Hemşirelerde İş Doyumunu Etkileyen Faktörler. Yoğun Bakım Hem Derg 2005;9:8-13.

5. Çam O, Yıldırım S. Hemşirelerde İş Doyumu ve Etkileyen Faktörler. Türkiye Klinikleri J Nurs Sci 2010;2:64-70.

6. Aksoy N, Polat C. Akdeniz Bölgesindeki Bir İlde Üç Farklı Hastanenin Cerrahi Birimlerinde Çalışan Hemşirelerin Işs Doyumu ve Etkileyen Faktörler. HEAD 2013;10:45-53. Erişim: http://www.journalagent. com/kuhead/pdfs/KUHEAD_10_2_45_53.pdf

7. Park M, Lee JY, Cho SH. Newly Graduated Nurses' Job Satisfaction: Comparison with Allied Hospital Professionals, Social Workers, and Elementary School Teachers. Asian Nurs Res 2012;6:85-90. [CrossRef]

8. Tilev S, Beydağ KD. Hemşirelerin İş Doyum Düzeyi. Sağlık Hem Yön Derg 2014;3:140-147. [CrossRef]

9. Meyer RML, Li A, Klaristenfeld J, Gold Jl. Pediatric Novice Nurses: Examining Compassion Fatigue as a Mediator Between Stress Exposure and Compassion Satisfaction, Burnout, and Job Satisfaction. J Pediatr Nurs 2015;30:174-83. [CrossRef]

10. Tambağ H, Can R, Kahraman Y, Şahpolat M. Hemşirelerin Çalışma Ortamlarının İş Doyumu Üzerine Etkisi. Bakırköy Tıp Derg 2015;11:143-9. [CrossRef]

11. Abualrub R, El-Jardali F, Jamal D, Al-Rub NA. Exploring the Relationship Between Work Environment, Job Satisfaction, and Intent to Stay of Jordanian Nurses in Underserved Areas. Appl Nurs Res 2016;31:19-23. [CrossRef]

12. Durmuş $S$, Günay $O$. Hemşirelerde İş Doyumu ve Anksiyete Düzeyini Etkileyen Faktörler. Erciyes Tıp Derg 2007;29:139-46. Erişim: https:// www.journalagent.com/erciyesmedj/pdfs/EMJ_29_2_139_146.pdf

13. Zangaro GA, Soeken KL. A Meta-Analysis of Studies of Nurses' Job Satisfaction. Res Nurs Health 2007;30:445-58. [CrossRef]

14. Erbil N, Bostan Ö. Ebe ve Hemşirelerde Iş̧ Doyumu, Benlik Saygısı ve Etkileyen Faktörler. Atatürk Üniv Hem YO Derg 2004;7:5666. Erişim: http://earsiv.odu.edu.tr:8080/xmlui/bitstream/ handle/11489/442/281-1094-1-PB.pdf?sequence=1\&isAllowed=y

15. Kahraman G, Engin E, Dülgerler ş, Öztürk E. Yoğun Bakım Hemşirelerinin iş Doyumları ve Etkileyen Faktörler. DEUHYO ED 2011;4:12-8.

16. Yu H, Jiang A, Shen J. Prevalence and Predictors of Compassion Fatigue, Burnout and Compassion Satisfaction Among Oncology Nurses: A Cross-Sectional Survey. Int J Nurs Stud 2016;57:28-38. [CrossRef]

17. Bezirci SŞ. Farklı Kuşaklardaki Hemşirelerin Meslekten ve İşten Ayrılma Niyetleri İle İş Doyumlarının İncelenmesi. Dokuz Eylül Üniversitesi Sağlık Bilimleri Enstitüsü, Yüksek Lisans Tezi. İzmir; 2012.

18. Cogin J. Are Generational Differences in Work Values Fact or Fiction? Multi-Country Evidence and Implications. Int J Hum Resource Manag 2012;23:2268-94. [CrossRef]

19. Türk Dil Kurumu (TDK) Sözlükleri. http://www.tdk.gov.tr/index. php?option=com_gts\&arama=gts\&guid=TDK.GTS.5b170fe1a92c75 03165371 Erişim Tarihi: 7 Haziran 2018.

20. Duchscher JEB, Cowin L. Multigenerational Nurses in The Workplace. J Nurs Admin 2004;34:493-501. [CrossRef]
21. Carver L, Candela L. Attaining Organizational Commitment Across Different Generations of Nurses. J Nurs Manag 2008;16:984-91. [CrossRef]

22. Lipscomb VG. Intergenerational Issues in Nursing: Learning From Each Generation. Clin J Oncol Nurs 2010;14:267-9. [CrossRef]

23. Wilson B, Squires MAE, Widger K, Cranley L, Tourangeau A. Job Satisfaction Among A Multigenerational Nursing Workforce. J Nurs Manag 2008;16:716-23. [CrossRef]

24. Kenny P, Reeve R, Hall J. Satisfaction with Nursing Education, Job Satisfaction, and Work Intentions of New Graduate Nurses. Nurs Educ Today 2016;36:230-5. [CrossRef]

25. Coburn AS, Hall SJ. Generational Differences in Nurses' Caracteristics, Job Satisfaction, Quality of Work Life, and Psychological Empowerment. J Hosp Admin 2014;3:124-34. [CrossRef]

26. Weiss DJ, Dawis RV, England GW. Manual for the Minnesota Satisfaction Questionnaire. Minnesota Stud Vocational Rehabil 1967;22:120.

27. Baycan A. An Analysis of The Several Aspects of Job Satisfaction Between Different Occupational Groups. Boğaziçi Üniversitesi Sosyal Bilimler Enstitüsü, Yüksek Lisans Tezi. İstanbul; 1985.

28. Karasu F, Aylaz R. X ve Y Kuşağı: Hemşirelerin Meslek Dayanışması ile İs Doyumu Arasındaki Illişki. Sağlık Bilim Meslek Derg 2017;4:180-9. [CrossRef]

29. Sparks AM. Psychological Empowerment and Job Satisfaction Between Baby Boomer and Generation X Nurses. J Nurs Manag 2012;20:451-60. [CrossRef]

30. Walker A, Campbell K. Work readiness of graduate nurses and the impact on job satisfaction, work engagement and intention to remain. Nurs Educ Today 2013;33:1490-5. [CrossRef]

31. Çalışan A, Ergun YA. Examining Job Satisfaction Burnout and Reality Shock Amongst Newly Graduated Nurses. Procedia-Social Behav Sci 2012;47:1392-7. [CrossRef]

32. Tarcan M, Hikmet N, Schooley B, Top M, Tarcan GY. An Analysis of The Relationship Between Burnout, Socio-Demographic and Workplace Factors and Job Satisfaction Among Emergency Department Health Professionals. Appl Nurs Res 2017;34:40-7. [CrossRef]

33. Mert Haydari S. Farklı Kuşaklardaki Hemşirelerin Meslekten ve İşten Ayrılma Niyetleri Ile Örgütsel ve Mesleki Bağlılıklarının İncelenmesi. Dokuz Eylül Üniversitesi Sağlık Bilimleri Enstitüsü, Yüksek Lisans Tezi. İzmir; 2014.

34. Selçuk Çınar E. Farklı Kuşaklardaki Hemşirelerin Çalışma Ortamları Algısı İle İşten ve Meslekten Ayrılma Niyetinin İncelenmesi. Dokuz Eylül Üniversitesi Sağlık Bilimleri Enstitüsü, Yüksek Lisans Tezi. İzmir; 2016.

35. Arıkan F, Köksal CD, Gökçe Ç. Work-Related Stress, Burnout, and Job Satisfaction of Dialysis Nurses in Association With Perceived Relations With Professional Contacts. Dial Transplant 2007;36:182-91.

36. Bitek DE, Akyol A. Yoğun Bakım Hemşirelerinin Çalışma Ortamına İlişkin Algıları ile İş Doyumları Arasındaki İlişkinin İncelenmesi. Yoğun Bakım Hem Derg 2017;21:1-6. Erişim: https://dergipark.org. tr/download/article-file/335742

37. Öztürk H, Kasım S, Kavgacı A, Kaptan D, İnce G. Bir Üniversite Hastanesinde Çalışan Hemşirelerin İs Doyum Düzeyleri. J Anatolia Nurs Health Sci 2015;18:17-25. [CrossRef]

38. Tao $\mathrm{H}$, Ellenbecker $\mathrm{CH}$, Wang Y, Li Y. Examining Perception of Job Satisfaction and Intention to Leave Among ICU Nurses in China. Int J Nurs Sci 2015;2:140-8. [CrossRef]

39. Uğur Gök A, Kocaman G. Reasons for Leaving Nursing: A Study Among Turkish Nurse. Contemp Nurs 2011;39:65-74. [CrossRef]

40. Nogueras DJ. Occupational Commitment, Education, and Experience As a Predictor of Intent to Leave The Nursing Profession. Nurs Econ 2006;24:86-93. 
41. Simon M, Müller BH, Hasselhorn HM. Leaving The Organization or The Profession -a Multilevel Analysis of Nurses'Intentions. J Adv Nurs 2010;66:616-26. [CrossRef]

42. Robson A, Robson F. Do Nurses Wish to Continue Working for The UK National Health Service? A Comparative Study of Three Generations of Nurses. J Adv Nurs 2015;71:65-77. [CrossRef]

43. Chang CS, Du PL, Huang IC. Nurses' Perceptions of Severe Acute Respiratory Syndrome: Relationship Between Commitment and Intention to Leave Nursing. J Adv Nurs 2006;54:171-9. [CrossRef]

44. Kropp W. One Voice of Generation Y. Front Health Serv Manag 2012;29:40-4. [CrossRef]
45. Radford K, Shacklock KH, Bradley GL. Battle of The Decades: Generational Differences in the Retention of Australian Aged Care Employees. Emerging Researcher in Ageing, Conference Proceedings. Brisbane, 19-20th November 2012; pp.86-9.

46. Takase M, Oba K, Yamashita N. Generational Differences in Factors Influencing Job Turnover Among Japanese Nurses: An Exploratory Comparative Design. Int J Nurs Stud 2009;46:957-67. [CrossRef]

47. Fochsen G, Sjögren K, Josephson M, Lagerström M. Factors Contributing to The Decision to Leave Nursing Care: A Study Among Swedish Nursing Personnel. J Nurs Manag 2005;13:338-44. [CrossRef] 